NBER WORKING PAPER SERIES

TESTS OF EXCESS FORECAST

VOLATILITY IN THE FOREIGN

EXCHANGE AND STOCK MARKETS

Kenneth A. Froot

Working Paper No. 2362

NATIONAL BUREAU OF ECONOMIC RESEARCH

1050 Massachusetts Avenue

Cambridge, MA 02138

August 1987

I am grateful for discussions with Charles Engel, Jeff Frankel, and Julio Rotemberg, and to Alberto Giovannini for help in obtaining data. The research reported here is part of the NBER's research programs in International Studies and Financial Markets and Monetary Economics. Any opinions expressed are those of the author and not those of the National Bureau of Economic Research. 
Tests of Excess Forecast Volatility

in the Foreign Exchange and Stock Markets

\section{ABSTRACT}

Simple regression tests that have power against the aiteniatives that asset prices and expected future asset returns are excessively volatile are devrloped and performed for the foreign exchange and stock narkets. These tests lave a number of advantages over alternative, variance bounds techniques. We fincl evideuce that both exchange rates and stock prices are excessively volatile and that expected returns on foreign exchange and stocks move too much. We also investigate whether these findings can be attributed to time-varying risk premia, but in our tests the data provide little support for such an alternative hypothesis.

Kenneth A. Froot

Sloan School of Management MIT

Cambridge, MA 02139 


\title{
Tests of Excess Forecast Volatility \\ in the Foreign Exchange and Stock Markets
}

\author{
Kenueth A. Front \\ Sloan School of Managemrnt. \\ Massachusetts Instituter of Trehunology \\ Cambridge, Massachusetts 02139
}

Begimuing with Robert. Shiller (1981a), variance bounds tests of market efficiency have generated an enormous amomit of rescarch. Such tests are wirlely viewerl as all altcruative technique to their predecessors, simple reglession tests of market effiriency. Surprisingly little cnergy, however, has been applied to examining whether particular regressinu tests ran uncover evidence for the same types of altemative hypotheses as tests of variaure bounds. This paper develops simple regression tests with power against the alternative hypotlieses that asset prices and expectations of future asset returus are excessively volatile, and it applies these trats to the foreigu exchange and stock markets.

In the case of the foreign exchange market. several authors investigate the volatility of spot rates. ${ }^{1}$ They constinct variance bounds relations based on monctary modrels of exchange rate determination, and their results provirle no support for thr view that exchange rates are excessively volatile. ${ }^{2}$ But economists seem to plare lit.te faith in these tests. regardirss of the results, because the models used to construct the varianer ineculalities perfol'm so poorly wlien tested alone, and because the assumptions of these morlels (such as purchasing powe'l parity) are so egregiously violated in the data. Anong a wider andicure. the belief that exchange rates are excessively volatile is widely and unreflectively held, manifesting itself in recrut proposals for international macroeconomic policy coordination and the adoption of exchange rate target zones.

There is a similar lack of consensus on the prescure of excess volatility in the stock market.

\footnotetext{
'See Huang (1981), Vander Kraats and Booth (1983), and Mcesr aurl Singleton (1983).

${ }^{2}$ Huang (1981) and Vander Kraats (1983) at,tribute the violation of thrir variaure inequalities to excessive variability. A receut note by Behzad Diba (1987), however, shows that. these results grst. nu a common calculation error. and that the bounds are in fact satisfied once the error is corrected.
} 
Early tests showed that variance bounds based on simple present value models were strongly violated. A number of later researchers, however, pointed out that the time-series properties of prices and dividends were crucial in these rejections. ${ }^{3}$ Recently. Camplocll and Shiller (1987) allow real prices and dividends to contain unit. roots and find that, while the present value model of the stock price can be statistically rejected, violations of the variance inequalities are not statistically significant.

The regression tests of excess volatility we develop lielow have scveral artvantages over methods used previonsly in the exanimation of excliange rates and stcıck prices. First. they do not rely on a complete specification of the underlying fundannentals which ultimately determine asset values. This is important for assets such as forcign currencies. for whicl there is no ardequate nodel of fundamentals. Second, the tests do not require knowledge of the stocliastic processes driving the fundainentals. The results of varianer bounds tests for 'xressive stock price variability, for example, have been questioned based on their assmunptions about the driving processes. Third, our stock price tests allow for a tinir-varying discount factor. This is important because nany observers have suggested that the constant discount rates cmployed in many tests could account for findings of excessive volatility. Fourth, our tests have rqual power against the opposite alternative hypothesis, that asset prices and expected returns are insuffiriently volatile. Fiftll, the tests are simple. Indeed, they are versions of particnlar efficient market tests with precise interpretations given to the alternative hypotheses in cach case. Finally, the tests appear to have power against these alternatives. While we do not specifically compare their power with other test methodologies in simulations, we use them on actual data and find substantial evidence of excessive volatility of prices and of expected future returns in both the foreign excliange and stock markets.

Of conrse, failures of market efficiency may loc altermatively attributed to risk premia that vary in ways not specified by the underlying model. We attempt te shed light om the importance of this alternative hypothesis in two ways. First, we employ survey data on excliange rate expectations in order to get around the presence of the exchange rate risk premimm that contaminates forward rates. Second, we ask whether the volatility of stock market ret.nrns can accomnt for the hypothesized behavior of the equity premium. Both of these techuiques suggest that our results are not primarily

\footnotetext{
'See Shiller (1981a), LeRoy and Porter (1981), Kleirlon (1986), Marsh and M(nztnu (1986). Want (1084); and Mankiw, Romer and Shapiro (1985).
} 
a consequence of time-varying risk premia.

The paper is organized as follows. In section I. w' discuss the relationship between variance bounds tests of asset price volatility and simple regressinu trists of market efficiency. While straightforward, this relationship seems to be lost in the literaturr. We then propose in section Il a different definition of the concept that asset prices are "ton" volatilu, racess forncast volatility. This definition has clear economic neaning, curompasses the usual variance boumrls restrictions, and is nost directly put to use in a regression framework. In an effort to stress that the issues raised in the first two sections are quite general, sections III and IV apply the tests to the forcign exchange market and the U.S. stock market, respectively. Section V couchides.

\section{Comparison of Regression Tests with Variance Bounds}

Consider an attenipt to forecast a stationary varialule. $f_{;}^{*}$, iu which the forecast is denoted by $f_{\text {, }}$ and the prediction error by $\epsilon_{\ell}$ :

$$
\mathbf{f}_{i}^{*}=\mathbf{f}_{\mathbf{t}}+\mathrm{t}_{\mathbf{t}}
$$

If the forecast is optimal, then equation (1.1) gives rise to the noual upper and lower bounds on the variance of the forecast and the prediction crror:

$$
\begin{aligned}
& \operatorname{var}\left(f_{t}\right)<\operatorname{var}\left(f_{f}^{*}\right) \\
& \operatorname{var}\left(f_{l}\right)<\operatorname{var}\left(f_{f}^{*}\right)
\end{aligned}
$$

Clearly, a violation of the upper variance bound in rquation (1.2a) implies that $f_{f}$ is "too" variable. In this section we relate this notion of excessive variability to the corfficicnts in simple regression t.ests.

Under the altemative hypothesis that the forecast is not efficient, thr variance of the prediction error term, $\epsilon_{l}$, may be expressed:

$$
\begin{aligned}
\operatorname{var}\left(\epsilon_{t}\right) & =\operatorname{var}\left(f_{t}^{*}\right)-\operatorname{var}\left(f_{t}\right)-2 \operatorname{cov}\left({ }_{1}, f_{t}\right) \\
& =\operatorname{var}\left(f_{l}^{*}\right)+\operatorname{var}\left(f_{t}\right)-2 \operatorname{cov}\left(f_{t}^{*}, f_{t}\right)
\end{aligned}
$$

From these two expressions, the necessary and sufficient comditions for the variance bounds to be satisfied are:

$$
\operatorname{var}\left(f_{i}^{*}\right)>\operatorname{var}\left(f_{t}\right) \quad \Leftrightarrow \quad \frac{\operatorname{cov}\left(\epsilon_{t} \cdot f_{t}\right)}{\operatorname{var}\left(t_{1}\right)}>-\frac{1}{2}
$$




$$
\operatorname{var}\left(f_{f}^{*}\right)>\operatorname{var}\left(c_{1}\right) \quad \Leftrightarrow \quad \frac{\operatorname{cov}\left(c_{1}, f_{f}\right)}{\operatorname{var}\left(f_{f}\right)}>-\frac{1}{2}
$$

In words, the upper bound in equation (1.4a) is satisfied if and only if the rocfficient in a regression of the forcrast, $f_{t}$, on the prediction error, $\epsilon_{l}$, yiclels a cocfficicut greater than $-1 / 2$. The sccond, or lower, variance bound in equation $(1.4 \mathrm{~b})$ is satisfierl only wlien the coefficient in the opposite regression - in whicl the prediction error, $c_{,}$, is projecterl outo $f_{f}$ is greater than minus one half. In practice, the latter regression is more convenient. to mul lecranse the mull liypothesis implies thlat. $f_{t}$ is purcly random. Either way, in the regression test the joint maintaincl lypothesis that

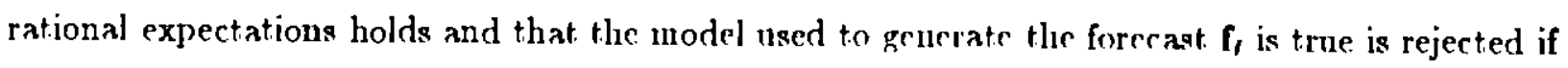
the coefficient is statistically different from $x$, ro.

A more complete comparison of the relationship betwern the iegression parameters and the variance inequalities is presented in Figure 1. In a regression of tlue prediction error on the forecast,

$$
c_{t}=\alpha+\beta f_{1}+\eta_{l}
$$

there is a direct mapping between the coefficient estimate anrl the validity of the lower bound (equation (1.4b)): if $\beta<-1 / 2$ the lower bound is violaterl and if $\beta>-1 / 2$ the lower bound is satisfied. A finding that $\beta$ is positive indicates that botll inequalities $1.4 \mathrm{a}$ and $1.4 \mathrm{~b}$ are satisfied. Notice that if $\operatorname{var}\left(f_{t}\right)>\operatorname{var}\left(f_{i}^{*}\right)$, the regression test will detect the violation. and the parameter estimate will be negative. But the converse is not true. If the paranleter rstimate is negative, it need not follow that the upper bound is violated. The locttoul lialf of Figure 1 shows that the opposite regression test yields all the same couclusinus, lut fol the opposite variance bounds.

Suppose for example that the variable we are trying to forecast. $f_{f}$, is identically zero for all

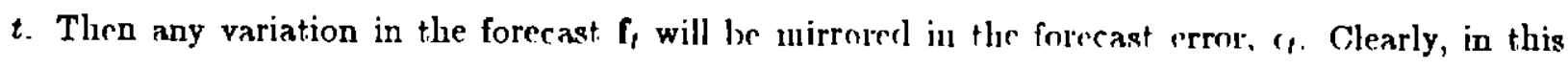
special case both the forecast error and the forecast are 'xecssively variable, so that both variance bounds will be violated. The regression in equation (1.5), as well as the opposite regression of the forecast on the prediction error, will yield $\beta=-1$.

Figure 1 indicates that the unconditional variance boumds incoualitics above lave less power to distingtuish correlation between the forecast and thle prediction crror thlan do the regression tests: the former require that $\beta<-1 / 2$, whereas the latter allow ns to reject whenever $\beta<0$. Such correlation is a clear signal that forecasts can be made more efficint. But while the relative power of 
regression versus variance bounds tests has bern rliscusserl extensively. ${ }^{4}$ it is not the only important issue in comparing these two test nothodologies. First of all. comecntrating ouly on the subject of power obscures the fact that both types of tests are based mo a single covariance restriction, expressed in equation (1.4). Sccond of all, when there are several ways of testing the efficiency of forecasts, it is worthwhile to ask how woll cach mothorl distiuguishers anıng rompeting alternative hypotheses, not. just. how well each distinguishes between the mull hypothesis and a particular alt.cruative. For instance, one might pose as an alternative hypotlesis that rertain forecasts are insuffiriently volatile. Before rejecting out of hand such an altrunative, it is worth recalling that investigations of the term structure of interest pates have found rrpeatedly that long rates nove too little relative to short rat.cs. ${ }^{5}$ Unlike regression tests, varianer bomuls tests are umable to uncover evidence of insufficient volatility in asset prices.

\footnotetext{
'See Flavin (1983), Stuller (1981b), and Frankel and Stock (1987)).

${ }^{5}$ Mankiw and Summers (1984), Shiller, Campbrll and Schornholt.7 (1983) and Camplirll and Slillor (1984) conelude that the long rate underreacts to the short rate. Froot (1987a) usrs s1n'ry rlata nil intrrat rate rxpectations to tetermine whether changing term premia can account for this result.
} 


\section{Excess Forecast Volatility}

What makes a forecast. "too" variable? While a violation of the npper variance bound in equation (1.2a) is a striking example of incfficient forceasting. its ecounmic siguificance lies in the fact that the prediction errors, $\epsilon$ are necdlessly large. The mean sculuared prediction error could be reduced simply by lowering the variance of the forecast arnumd its nuean. Similarly, violation of the lower variance bound implies that a marginal reduction in the varianes of the forecast will reduce the mean squared prediction error. Thus the necrssary and sufficicut condition for a forecast. to be excessively volatile is that a reduction in the variance of the forecast. reduces the mean squared prediction error. An "insufficientily" volatile foresast is our that can be inpreved upon merely by increasing the forecast variance.

It is intuitively clear that such a test for excessive or iusufficiont forecast volatility can be implemented by running a regression. The derivative of the menil scjuared foresast cror in equation (1.4b) with respect to the standard deviation of the forecast., $\pi_{\mathrm{f}}$. londing all clse constant is: ${ }^{6}$

$$
\begin{aligned}
\frac{\partial E\left(c_{f}^{2}\right)}{\partial \sigma_{\mathrm{f}}} & =2 \sigma_{\mathrm{f}}\left(1-\frac{\dot{\rho} \sigma_{\mathrm{f}}}{\sigma_{\mathrm{f}}}\right) \\
& =-2 \rho \sigma_{\mathrm{f}} .
\end{aligned}
$$

where $p^{*}$ is the correlation coefficient between $f_{f}$ and $f_{f}^{*}$. anr $p$ is the corrclation coefficient between $\epsilon_{f}$ and $f_{f}$. From the last term in expression (2.1). there is "Xcessive forenast volatility whenever $p$ is negative. Of course, the sign this last term is opposite to that of the slope cocfficient in a regression of the prediction error, $\epsilon_{8}$ on $f_{f}$. Thus the definitions of excessive aud insuffirient forecast volatility provide a complete set of alternative hypotheses in regressimus of $i f$ onl $\mathbf{f}_{t}$.

\section{Excess Variability of Exchange Rates}

We now formulate a general excliange rate model that allows na to test for excessive volatility in the spot exchange rate. Consider a model in which the log of the spot rate is equal the sum of

\footnotetext{
${ }^{6}$ In taking this derivative, we hold constant the varianee of the forer asterl varialyle, $f_{f}$. aq wroll an the correlation between

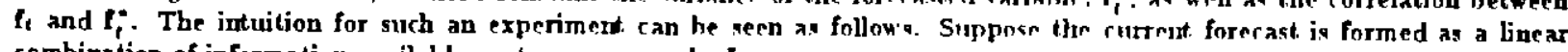
combination of information available contemporaneously, $I_{f}$ :

$$
f_{t}=\mathbf{n}+\mathbf{I}_{\mathbf{p}} \mathbf{b}_{\mathbf{r}} .
$$

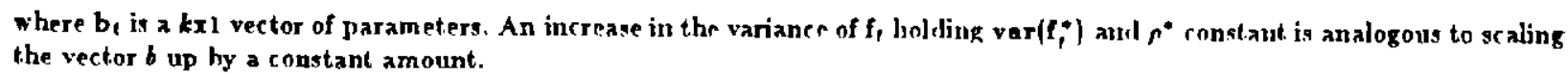


two things: an arbitrary transformation of a vector of funclancutals, anrl a speculative term based on expected future price changes, conditional on all currently available information:?

$$
\mathbf{s}_{t}=\mathrm{c}_{\mathrm{t}}+n \Delta \mathbf{s}_{t+1}^{e}
$$

where $a$ is a positive parameter, and $\Delta s_{t+1}^{e}$ is the experterl percentage depreciation in the spot rate between time $t$ and $t+1$. There are a munber of sperific exchange rate models which fit the form of equation (3.1), each of which leads to a different interpretation of the parameter $a$ and the fundamentals term $c_{f}$. For example, equation (3.1) can be interpreterd in trme of the flexibleprice monetary model of Mussa (1976), Frenkel (1976) and Bilsm (1978). Then a corresponds to the semi-elasticity of money demand with respect to the altemative rate of return (which would be the interest differential, expected depreciation or the inperted inflation differential), and $c_{\ell}$ is proportional to the log of the ratio of the domestir moncy sitpply to the forrign money supply, plus any other determinants of money demand. ${ }^{8}$ Variance boumds based on this version of the flexibleprice monetary model are considered by Huang (1981). Mrcse and Singleton (1983), Vander Kraats and Booth (1983) and Diba (1987).

Equation (3.1) is nsually solved iteratively, so that the spot price is expressed solely in terms of the expected future path of fundamentals: ${ }^{9}$

$$
\mathbf{s}_{\imath}=(1+a)^{-1} \sum_{j=0}^{\infty}\left(\frac{n}{1+a}\right)^{j} \mathbf{c}_{t+j}^{e}
$$

A perfect foresight price analogous to that of Shiller (1981n) would prevail if ageuts knew with certainty the actual future path of $c_{i}$ :

$$
\mathrm{s}_{i}^{*}=(1+n)^{-1} \sum_{j=0}^{\infty}\left(\frac{n}{1+a}\right)^{j} \mathrm{c}_{i+j}
$$

Under rational expectations the perfect foresight pricr, $s_{i}^{*}$. is the sum of the forecast, $s_{t,}$ phes an error term which is conditionally independent of contruporaneoms information:

$$
\mathbf{s i}_{i}^{*}=\mathbf{s}_{\mathbf{i}}+\epsilon_{i} .
$$

\footnotetext{
Frenkel and Mussa (1986) discuss various interpretations of this general morlel.

"Equation (3.1) can also be interpreted in terms of the sticky-monetary'morlel of Dornhusrly (1970) and Frankel (1979), portfolio halance models of the exchange rate, and in terms of a statio CACM mndrl.

${ }^{\circ}$ The solution given in equation (3.2) assumes that the transversality rondition holrk: $\lim _{j \rightarrow \infty}\left(\frac{a}{T+a}\right)^{j} \bullet_{i+j}^{e}=0$. Thus rational bubbles will violate any variance bounds constructerd using the formulation for a; in aquation (3.3).
} 
To inchuce stationarity, a näive forecast can be subtracted from both sjides: ${ }^{10}$

$$
s_{i}^{*}-x_{i}=s_{1}-x_{1}+1,
$$

The discussion in the previons sections suggests a regression of the prediction error, $\epsilon_{t}$, on the forecast. $s_{t}-x_{t}$, to test for excessive volatility. But since the crror trrm is not observable there is no direct way to implement such a test. If the itcration in rquations (3.2) and (3.3) stopped at a finite terminal date, as in Mankiw, Romer and Shapiro (1985), then the error term would be observable, but would be highly serially correlated. ${ }^{11}$

Even if the error and the perfect foresight spot rate are observable, there are several wellknown difficulties in implementing both the regressions and tersts of variance bounds based on equation (3.5). First, hoth tests assume that the vector of fumramentals (defincd here as everything influencing the currency but for expected future appreciation) is properly specified. In the case of the exchange rate, there is little agrecment on or evidenes in favor of a short list of important macroeconomic variables. The monetary model, which employs momcy supplies and measures of real income, is notorious for producing unstable cocfficient cstimates and for failing to account for any positive percentage of exchange rate movements. ${ }^{12}$ Even absent issues of imprecise measurement of income and money, few macroeconomists would argue that money demand is an exact linear function of these variables alone, or that purchasing power parity holds exactly in the short ruu.

Second, even if the model of fundamentals is not contentinus, variance bounds tests are not robust to misspecification of the dynamic process of the forring variables. The most obrious illustration is in the stock market. Marsh and Merton (1986). for example, show how measured variances will violate the upper variance bound in cvery sample if dividends follow a nonstationary process driven by lagged stock prices. ${ }^{13}$ The same sort of criticism applies to variance bounds relations in the foreign exchange market. In a direct analngy to the Marsh and Merton exanuple, if monetary policy is set in response to the (noustationary) exchange rate and if the monetary model is true, then measured variance bounds will be violated in every sample. Without precise knowledge of the stochastic process of $c_{1}$, small sample biases will plague unbiased ineasure ment of

\footnotetext{
10Mankiw, Romer and Shapiro (1985), and Frankel and Stock (1987) also use näive forec asts to iuduce stationarity.

"Scot. (1985) discusses the serial correlation properties of meh an mrror. and uers it. in a regression trest. of excessive volatility in the stock market.

${ }^{12}$ See Frankel and Meese (1987) for the implic ations of the empiric al failuren of this morlel.

${ }^{18}$ Camphell and Shiller (1987) cannot reject the hypothesis that real dividende rout.xin $x$ unit ront.
} 
the variances. ${ }^{14}$

These difficulties can be avoided by deriving tests which do unt repuire iteration of equation (3.1). Consider an alternative perfert fnresiglit price. s, ${ }^{* *}$ which prevails if agents know with certainty the subsequent change in the spot rate:

$$
\mathbf{s}_{t}^{* *}=\mathbf{c}_{\mathfrak{t}}+a \Delta \mathbf{s}_{t+1}
$$

Whider rational expectations, this perfect foresight spet rate is the sum of the forceast, $\mathbf{s}_{t}$, plus an error tern that is conditionally independent of contemporanemes information:

$$
\mathrm{s}_{1}^{* *}-x_{1}=\mathrm{s}_{1}-x_{1}+\mathrm{\prime}_{1}
$$

where we have subtracted the näive forecast from botli s;" and $\mathbf{s}_{\text {I. }}$.

The prediction error $\epsilon$, now las a simple interpertation. in that it is proportional to the error made when predicting the subsequent spot rate:

$$
c_{1}=a\left(s_{1+1}-s_{1+1}^{e}\right)
$$

The one period difference in dating of the right- and left-lianrl sides of ecpuation (3.8) implies one need not wait many periods (or forever) to observe the perfect fnresight crror: it is known at time $t+1 .{ }^{15}$ In addition, the error is serially uncorrelated mucler tlu unll hypothesis, a desirable property for our regression tests.

While $c_{\ell}$ is itself mobservable, we call nevertheless draw consistent inferences about its behavior. Most of the models mentioned above. including the monetaly models tested by Huang (1981) and Vander Kraats and Booth (1983), assume that covered and nucovered interest parity hold, i.e. that assets denominated in different currencies are perfect substitutes. These assuniptions imply the forward discount is equal to expected depreciation:

$$
f d_{1}=\Delta s_{1+1}^{e}
$$

\footnotetext{
14 Papers discussing these prohlems jnclude Marsh and Merton (1980), Klejion (1988), Flavin (1983), Mankiw, Romer and Sliapiro (1985), Matley and Mease (1987), and Frankel and Meesr (1987). Ser alon Camplorll and Sliller (1987) who use the theory of co.jntegration to allow for nonstationarity in asset pries and tlie forring variahles.

is This removes one important critieism of the regression-based tests xr druclop helow. Shiller (1081h), for example, argues that because asset prices depend on the discounted value of an infinitr strram of future fundameitals, the perfect foresight error will not be fully known in a given sample, and this regression trots will sulfer from a "rata alignment" problem. The perfect foresight. error in equation (3.6) is not subjert to this prohlem.
} 
where $f d$ is the log of the forward rate mimus the Ing of the spot rate. Of course, if the forward discomnt exceeds expected depreciation by a constant risk preminum. we call still draw inferences about the perfect foresight prediction error. In this case the forer ast error, 4, is an affine trausformation of the forward rate prediction error, $\mu_{1+1}^{\prime}=\Delta s_{t+1}-f l_{l}$, which is observable one period later and is not dependent on precise specification of the fundanmental variables:

$$
\epsilon_{1}=a\left(\mu_{1+1}^{\prime}\right)-a \lambda
$$

The exchange risk preminm term, $\lambda$, is zero if equation (3.9) holds exactly.

From equation (3.7), the spot rate is ton variable around $x$, if the coefficient in a regression of $\mu_{1+1}$ on $s_{f}-x_{l}$ is negative, and not variable enough if the enefficient is positive. This inference holds cron though the parameter $a$ is unknown. In contrast. it is not possible to test the validity of variance bounds constmeted from equation (3.7) muless the value of $n$ is kuowu. Indeed, the appropriate magnitude of a has bern a point of contention. Hualıg (1981) aud Vander Kraats and Booth (1983) both find evidence that varianes bounds are violated based nn their assumed values of the semi-elasticity of money demand, a. Deba (1987) argnes in response that the values these anthors chose for a are too low, and that the variauce ineculalities are satisfied for larger, more plausible semi-elasticities. Our regression tests, however. call remain aglostic on the precise value of $a$, as Iong as it is positive. The regressions also do uot place any restrictions on the identity of the fundamental variables inchuded in $c_{1}$, or on the stochastir processes geuerating these variables.

Next we turn to candidates for the naive forecast. a. . One potential candidate is the log of the lagged spot rate, so that the deviation of the current spot late from $x$, is just the lagged percentage

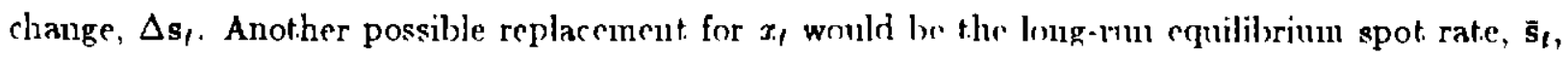
which evolves over time according to relative inflation rates in the two coumtrics. Note that if the long-run equilibrium is constant, then the log of the spent jate is itself statinuary, and, in ternis of equation (1.1), we call regress $\epsilon_{l}$ on $f_{i}$ directly.

\subsection{Tests of Excessive Forecast Volatility in the Spot Exchange Rate}

We can now test whether spot exchange rates are excessively variable. Our regressions in this section will be of the form:

$$
\mu_{l+1}^{\mathbf{f}}=\alpha+\beta\left(\mathbf{s}_{l}-x_{l}\right)+\eta_{l+1} .
$$


The null hypothesis is that the spot rate is an efficient forecast of $\mathbf{s}_{;}^{* *}$. or that $\alpha=\beta=0$, and the error term, $\eta_{1, t+1}$, is purely random. Before procecting to the estimntion, we make several general points about the specification of equation (3.11).

First, in the discussion so far and in Tables la. 1h, and le below. we use tle forward rate as a proxy for the expected future spot rate, as in equatiou (3.9). This is useful bec ause the nonetary inodel tested by Huang (1981), Vander Kraats and Booth (1983) and Diba (1987), as well as many other exchange rate models, take the forward rate to be equal to the expected future spot rate.

Second, if this assumption is relaxed (as it would be in a more gencral model), the forward rate would be the sum of a time-varying risk prenium and the experted future spot rate. Since the forward rate prediction errors will also inchde the risk preminum. hiased restimates of $\beta$ will result. One solution to this problem (other than assuninge it awny) would be to use in place of the forward rate another data source that does not suffer from thri interference of a risk premium, such as survey data on excliange rate expectatious. By using these data iu the second set of tables below, we attempt to auginent the generality of our estimates of $\beta$ in expuntion (3.11) beyond those that would be implied by restrictive models that assume the risk preminu does not change over time. ${ }^{16}$

Third, sone estimates of equation (3.11) already appear in the literature. only with a different interpretation attached to the alternative hypothesis, $\beta \neq 0$. Indecd. Frankel and Froot (1987) present estimates of equation (3.11) for all of the caurlidates for $x$, mentioned in the preceding section. They interpret the results in the same way as have previous authors: as statements about the beliavior of expectations, instead of statements about tle bellavior of the spot rate. To see this alternative interpretation, posit a particular model of expectations formation:

$$
s_{i+1}^{e}=\left(1-\theta_{1}\right) s_{t}+\theta_{1} x_{f} .
$$

which says that the expected future spot late is formed as a weighted average of the conteinporaneous spot rate and the other elenient, $x_{i}$. The actual spot prociss is then assulued to follow:

$$
\mathbf{s}_{t+1}=\left(1-\theta_{2}\right) s_{t}+\theta_{2} x_{t}+\eta_{t+1} \text {. }
$$

\footnotetext{
${ }^{16}$ To guarantee consistent estimates of $\beta$, we asaume that the mediaus survey reaponor is roplal to "thre" (unobservable) market expectation pliss random measurement error.
} 
Equation (3.11) can be obtained by subtracting equation (3.14) from (3.13), so that $\beta=\theta_{1}-\theta_{2}$. It follows that if expectations place too little weight on the "other" information $z_{\text {f }}$ (or too much weight on the contemporancous spot rate) relative to wlat is rational, $\beta<0$. In the case where $x_{1}$ is the long-run equilibrium spot rate. for example, a finding that $\beta$ is negative implies that. expectations are insufficiently regressive.

Fourth, several issues of econometrics should be mentinuerl before we procecd. Equation (3.11) and other equations that follow can be estimated using OLS with witl standard errors calculated using Hansen's (1982) Generalized Method-of-Mnments (GMM). Where appropriate, the covariance matrix estimators allow for scrial correlation inclucerl under the null hypothesis by overlapping observations. Due to the downwarel finite-sample hias of the heteroskedasticityconsistent GMM covariance estimates, we report two sets of standarel errors for the coefficients. The upper set are calculated assuming the residuals are linmoskedastic. and the lower set allow for unkunwn conditional leternskedasticity. If we wish to be on the safe sirte, we should weigh this downward bias more heavily than a loss in power. and therefore draw inferences based on the larger of the two reported standard errors. ${ }^{17}$ We use Sermingly Unrelatecl Squares (SUR) to estimate parameter estimates for all the curreucies combinerl in Talıles 1a. 1b and 1c. SUR is consistent and asymptotically efficient in the absence of couditional heteroskedasticity and the presence of contemporaneous correlation. Finally, in all of the regressions eacli currency was given its own constant terms, which we do not report to save spare.

\subsection{Results}

We now turn to the estimation of equation (3.11). Tables 1a. 1b. and 1c cmploy the forward rate as a measure of the expected future spot rate for earh of the varinus $x_{i}$ 's discussed above. The data are monthly obscrvations on six currencies from .Jum 1973 to Feloruary 1987. Tables 2a through 2c follow the same pattern, but instead use exchange rate survey clata from Money Market Services (MMS) to measure expected depreciation during the jeriod from .January 1984 to February 1986 .

Table 1a tests the case in which the long-run equilibrium spot rate is treated as an arbitrary

\footnotetext{
${ }^{17}$ See Froot (1987b) for evidence of the downward hias in heternakedastirity-rnusietent standard arrnrs. The bias is present regardlest of the presence of conditional heteroskedantirity.
} 
constant, so that the log level of the spot rate is presumerd to be statinuary. Eacl of the point estimatce of $\beta$ is negative, indicating excessive volatility. The measurerl coefficienta for the individual culrencies are not very precise, however. To check whether an StIR estimator was appropriate, White (1980) tests of conditional heteroskedasticity wert performed for each currency, and none rejected the hypothesis that the residnals are homoskerlastic. ${ }^{18}$ When we combine all six currencies, lowever, the data reject the hypothesis that $\beta=0$ at the 5 perent level. In Table $1 \mathrm{~b}$, we use a second measure of the long-run equilibrium spot rate. allowing it to r'volve over time according to infation differentials. Table 1e replaces $x_{\text {f }}$ with the log of the laggert spot rate. Both tables report results very similar to those in Table la: all of the point estimates of $\beta$ are negative, and the estimates for the combined currencies are signific antly less than zern.

One possible explanation for the uegative coefficients in Talles la-10 is that they are induced by errors in the measurement of the spett rate. The average of the bid and ask rates, which we nsed in the regressions, will overstate or understate the relevant price by a maximum of about 0.1 percent. Such measurement error by itself generates a negative regression coefficient since it is present in both the left- and right-liand side variables. The magnitude of this effect is given by:

$$
\phi=\frac{\operatorname{var}\left(v_{t}\right)}{\operatorname{var}\left(\Delta \theta_{l}\right)} \approx \frac{0.000001}{0.0011} \approx 0.0009
$$

where 0.0011 is the sample average variance of unouthly exchange rate changes. It appears that this sonre of measurement error would not be enough to explain more than a sull fraction of the magnitude of the estimated coefficients.

Tables 2a though 2c use survey data with forecast horizons of nue month or less in place of the forward rate. ${ }^{19}$ If the forward rate contains a time-varying risk preminu which is responsible for the negative parameter estimates, then we would expect very different estimates here. In fact, of the estimates in all three tables is negative, and the magnitudes are comparable to those in Tables $1 a, 1 b$ and 1c. Several of the estimates are even slightly more significant: we can reject $\beta=0$ at the five percent, level in two cases. ${ }^{20}$

\footnotetext{
19 The OLS regression errors turn out to he hetroskedastic whelin conclitioniug on the forwarcl disconnt, but not when conditioning on the contemporaneous gpot rate, previous spot. rate clianges. or inriatious frnm the loug-run pquilibrium (Tables $1 \mathrm{a}, 1 \mathrm{~b}$ and $1 \mathrm{c}$, respectively).

19 The surveys are conducted by AMS on a weekly or biweekly hasis for four currencirs (thle pound, DM, Swiss frane, and yen) against the dollar. See Froot and Frankel (19BO) and Domingurz (1986) for a irseription of thrse dat.a.

${ }^{20}$ Frankel and Froot (1987) present similar tests for surveys with forerast horizons of threr inonths or longer. They also find negative estimates of $\beta$, which can be interpreter in the present rontrxi as midener of exerssive volatility:
} 


\subsection{Tests of Excessive Speculation}

The framework set up in the first. two scctions alsn allows ns to ask whether expected depreciation is excessively or insufficiently variahle. Cousider a regression of the expectational error on expected depreciation:

$$
\Delta \mathbf{s}_{i+1}-\Delta \mathbf{s}_{i+1}^{e}=\alpha+\beta \Delta \mathbf{s}_{i+1}^{e}+\eta_{t+1}
$$

where the null hypothesis is again that $\alpha=\beta=0$, anr that thr resirnal is purcly random. The altemative hypothesis in this regression is exactly what Bilson (1981) teruud cexcessive speculation:" a finding that $\beta<0$ implies investors would do better to move their expectations of the future exchange rate toward the contemporaneous spont rat ${ }^{2}$. therehy rechucing the variability of expected depreciation. Indeed, if the spot rate follows a raninum walk, expected depreciation should he reduced toward zero. A prime motivation for investicratimg the varialility of expected depreciation comes from equation (3.1): if expected depreriation moves too much, this may cause the splot rate to be too variable.

If we take the forward discount to measure expecterl depreciatiou. then equation (3.14) is equivalent to the usual test of forward rate unbiaseducss. Table 3 presents estimlates of this specification on monthly data for the duration of the floating rate plerind. The estimates reaffirm what many papers testing forward rate unhiasedness have found: that the optimal forecast of the future spot rate change places negative weight on the forward rate. ${ }^{21}$ If one is to accept that the risk prenium is constant (or, somewhat more weakly. uneoriclaterl with the forward discount) then the significantly negative estimates of $\beta$ reported in Table 3 indicate that experted depreciation is excessively volatile. Indecd, nuany of the cocfficients in Table 3 arr significautly less than $1 / 2$, indicating that the lower variance bound in equation (1.4h) is vinlated. Huang (1984) compares directly the variance of the forward rate prediction error with the variance of spot rate changes. Although he finds that the point estimate variance of the forward ratr crrol is greater (so that the lower variance bound is violated), lie cannot reject the hypothesis that the variances are equal. In the same paper, he is able to reject using regression tests of the form of equation (3.14). This suggests that the regression framework may in practice have more power not mly in detecting the alternative of a nonzero covariance between the forecast and the forecast error but also in detecting

\footnotetext{
"Hodrick (1987) gives a thorough summary of the litrrature tenting for hias in the forwart rxchange rate.
} 
statistically significant violations of variance bounds.

Most authors interpret the results from regressinus suclı as tlose in Table 3 as evidence of a time-varying risk preminm contained in the forward risemult ${ }^{22}$ Oner agail, we can put the survey data on expected depreciation to use because they ale unt contaminaterl by a risk premium. Regressions of equation (3.14) are reported in Froot aurl Frankel (1986) for 3 different survey solurces over a variety of time periods and forecast horizons. ${ }^{23}$ All of the estimates of $\beta$ are all highly significant and negative, suggesting that the results reported in Tabld 3 are not evidence of a time-varying risk prenium, and that they reflect insteal ixerssively volatile expectations of futture depreciation.

\section{Tests of Excessive Forecast Volatility in the U.S. Stock Market}

Next we develop our regression tests of exerssive volatility in the stork market. A necessary first order condition frou a representative investor's utility mnximization statce that the real stock price must equal the expected future ratio of uarginal utilitirs. weiglited by future stock prices:

$$
\frac{\mathbf{P}_{t}}{\mathbf{q}_{t}}=E_{t}\left(\frac{-m_{t+1}\left(\mathbf{p}_{t+1}+\mathbf{d}_{l}\right)}{\mathbf{q}_{t+1}}\right)
$$

where $\mathbf{P}_{t}$ is the nominal stock price at time $t, \mathbf{d}_{\ell}$ is the current dividend payucut, $\mathbf{q}_{t}$ is the price of the consumption good, and $m_{t+1}=-\delta \frac{U^{\prime}\left(e_{t+1}\right)}{V^{\prime}\left(c_{t}\right)}$, the discounted ratio of the marginal utility of consumption in between periods $t$ and $t+1 .^{24}$ The associated first order condition for a nominally riskless bond is:

$$
\left(1+\mathbf{i}_{t}\right)^{-1}=E_{t}\left(\frac{-m_{t+1} \mathbf{q}_{t}}{\mathbf{q}_{t+1}}\right)
$$

Combining equations (4.1) and (4.2) and solving for $\mathbf{P}_{1}$ we liave that the uominal stock price is equal to the discoumted value of the next period price plus dividruds:

$$
P_{\ell}=\frac{P_{l}^{e}+\mathbf{d}_{\ell}}{\left(1+\mathbf{i}_{\ell}\right)(1+\lambda)}
$$

where $\lambda=\operatorname{cov}_{f}\left(\frac{-m_{t+1} a_{t}}{a_{t+1}}, 1+r_{t+1}\right)$, and $r_{t+1}$ is the realized return nu stocks. The perfect foresight price is then:

$$
\mathbf{P}_{i}^{* *}=\frac{\mathbf{P}_{i+1}+\mathbf{d}_{i}}{\left(1+\mathbf{i}_{i}\right)(1+\lambda)} .
$$

\footnotetext{
${ }^{22}$ See for example Hansen and Hodrick (1983), Hodrick and Srivastava (1984) and Fama (1984).

${ }^{23}$ See section 4, particularly Tables o and 7 . We do not. report the estimaten here hothl herallse tiliey are reported elsewhere and, in any case, are similar to those in Table 3.

"The way equation (4.1) is written, the forthcoming dividend or cnupon payment. ja fully know'n at time t. This is done merely to simplify the exposition; the following discussion also applies when the rash fox's over the intervening period are uncertain.
} 
We focus on nominal nagnitudes in equations (4.3) and (4.4) in order to avoid using aggregate price data which contain more noise than data on stock prices and rividends. Notice that the risk preminm, $\lambda$, is the sinn of three components:

$$
\begin{aligned}
& \operatorname{cov}_{1}\left(\frac{m_{t+1} \mathbf{q}_{t}}{\mathbf{q}_{t+1}}, 1+\mathbf{r}_{t+1}\right)=\operatorname{cov}_{1}\left(m_{t+1} \cdot \frac{1+\mathbf{r}_{t+1}}{1+\pi_{t+1}}\right) \\
& +E_{l}\left(m_{1+1}\right) \operatorname{cov}_{1}\left(r_{1+1}, \frac{I}{I+\pi_{1+1}}\right)+\operatorname{cov}_{1}\left(m_{1+1} \cdot \frac{1}{I+\pi_{1+1}}\right)
\end{aligned}
$$

The first term is the covariance of marginal utility with the subscepent real return on stocks - the usual reward for risk when returns are expressed in real terms. The scrond term is the covariance of stock retums and inflation. The third term is the rovarianre of marginal utility with infiation. For the time being we allow the discount factor. $\left((1+\lambda)\left(1+\mathbf{i}_{1}\right)\right)^{-1}$ to vary ouly with the nominal interest rate, holding $\lambda$ (and therefore the conditional covariances in equation (4.5) constant). Later we consider a generalization of this nodel, in which the ennditional envariances can also vary with price-dividend ratios and nominal interest rates.

The prediction error of the contemporancons stock price is:

$$
\begin{aligned}
& \epsilon_{\mathfrak{i}}^{\mathbf{P}}=\mathbf{P}_{\mathfrak{i}}^{* *}-\mathbf{P}_{\mathbf{l}}
\end{aligned}
$$

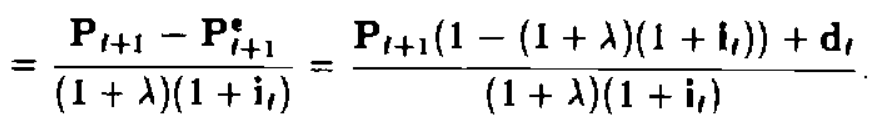

Dividing through by $x_{1}$ yields an equation in whirh carlo term is statinnary:

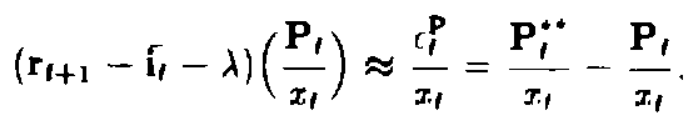

If the correlation of the modified prediction error on the left-hand side of equation (4.7) with $\frac{P_{t}}{x_{1}}$ is negative, stock prices are excessively volatile around $x_{1}$. Althougl thle prediction error, $t_{t}$ is not observable, we can observe the left-hand side of equation (4.7) np the a term proportional to $\frac{P_{1}}{x_{1}}$. Using equation (4.6), we have our regression equation:

$$
\mu_{i+1}^{\mathbf{P}}=\alpha+\beta \mathbf{p}_{l}+\eta_{1+1}
$$

where $\mu_{t+1}^{\mathbf{P}}=\left(\mathbf{r}_{t+1}-\mathbf{i}_{t}\right)\left(\mathbf{P}_{t} / x_{t}\right)$ is the adjusted excess return ou stocks over short-term nominally riskless bills, and $\mathbf{p}_{t}=\mathbf{P}_{\ell} / x_{l}$. The joint hypothesis that cquation (4.3) holds and expectations are 
rational implies that $\alpha=0, \beta=\lambda$ ancl the regidual is purnly paurlnm. Ecpuation (4.8) simply tests whether the one period excess return on stocks over Thills is systematically related to the current level of stock prices.

For stocks, the natural candidate for $x_{i}$ is the coutemproranemes dividend paynent, $\mathrm{d}_{t}$. The hypothesis that the price-dividend ratio is monstatinnary appeals to be strongly rejected, so that the usual asymptotic distribution theory can be applied in the regressions helow ${ }^{25}$ We therefore ask whether stock prices are excessivcly volatile around current rlividends. Inderd, there is atready some evidence that when the price-dividend ratio is low, rationally expected future excess returns are ligh. ${ }^{20}$

There are four main arlvantages to using equations (4.3) anrl (4.4) as npposed to an iterated version which expresses the price as a weighted average of experterd future dividends. First, it is easy to allow the discount factor $\left((1+\lambda)\left(1+i_{1}\right)\right)$ tn vary over tiurc. By contrast. iterated models quickly become intractable when the discount factor varies. ${ }^{27}$ It scems intuitively plausible that. discount factors vary considerably; allowing for this source of variation may well reverse many prior fundings of excessive variability in stock prices. A second advantage to allowing for a time-varying discount factor is that the specification in equation (4.4) can the'n be consistent with a wide range of utility functions. Most infinitely iterated solutions to equation (4.3) use a constant discount factor, and consequently, the associated perfect foresight price is cousistent witl utility maximization only if agents are risk neutral or if colsumption is perfectly fixed over time. The third advantage of this simple specification is that we can remain agmostic on the timc-series belaavior of the price and dividend processes, so long as the price-dividend latio is stationary. A fourtl advantage is that our regression equation (4.8) is insensitive to the price level. The rucess nominal return, $\mu_{t+1}^{P}$, is equal to the excess real return but for a constant term dnc to Jensell's inequality (the sum of the last two terms in equation (4.5)). Sinilarly, the price-dividend matio is maffected by the current price of consumption goods.

\footnotetext{
${ }^{25}$ See Camphell and Slitler (1987).

${ }^{26}$ See Flood, Hodrick and Kaplan (1980), Gamptell and Shiller (1987), and Fanta and French (1987) for evidence on the alility of the price-dividend ratio to predict. future stock returns. Krim anrl Stamlanigla (19BG) use a variety of proxies for stock prices, sucb as the stock prices of small-capitalization firms, to predirt. future retums on the market. They find evidence of substantial predictive powcr. In fact, their extimated coefficirnts arr all negative. tlongh tlary do not. interpret, this as evidence of excessive volatility.

${ }^{27}$ In their study of the behavior of the dividend-price ratio, Camphell ant Shiller (1987) avoid the added complexity by line arizing an infinitely iterated model.
} 


\subsection{Results}

Table 4 presents onr estimates of ecpuation (4.8). The clata on stork returns, both inclusive and exchusive of dividends, are the Center for Resenerh in Serurities Prices (CRSS) monthly valuewrighted index, whirh runs from 1926 to 1985 . Monthly interest rat.es on II.S. gevernment securities with approximately one month to maturity rome from Ibbotson Assoriates (198G). ${ }^{28}$ The first. row of Table 4 uses monthly data for the entire 60 year sample period. Monthly dividend measures rontain noise, however, since firns do not rlange their divirdend payme'nts earli month. One way to avoid this problem is to follow Camphell and Shiller (1987) and Marsls and Mertion (1987) by aggregating the data up to the annual level. Estimates of rquation (4.8) on annual data over the same period are presented in the second row of Table 4. The cstimate of $\beta$ is negative and statistically different from zero at the five perrent level. Infortmmately in this regression, excess ret.ums on storks were calenlated using a one-month riskless ratre rolled over, liecanse the Ibbotson data do not contain a riskless anmual rate. A second. and perliaps more satisfactory, means of climinating the measurement crror in monthly dividends wonld br to cmploy a moving average of dividend payments over the last 120 months. We term this näive forerast $d_{0}$, and use it for the regressions reported in rows 4 through 9 of Table 4 . This procedure has the advantage of allowing us to use the monthly data, so that the excess retiurus are computed above the appropriate riskless rate. The estimates for the entire sample period, reported in row 4, are negative and statistically different from zero at the five percent level.

\subsection{Excessive Volatility of Expected Stock Market Returns}

Analogously to section 4,2, we next ask whether expertert returns on the stock market are excessively volatile. In terms of the first two sections, the perfect foresiglut variable, $f_{l}^{*}$ can be interpreted as the realized gross nominal ret.urn on storks, and the forerast, $f_{f}$, ran be interpreted as the expected gross return. Equation (4.6) implies that the "xperted ret.mm is (approximately) equal to the nominal interest rate plus the preminu, $\lambda$. Thus amr irgression of $f_{f}$ on $f_{t}$ can be accomplished in this case by regressing the excess return on storks on a ronstant. and the nominal interest rate:

$$
\mu_{t+1}^{\mathbf{P}}=\alpha+\beta \mathbf{i}_{l}+\eta_{t+1}
$$

\footnotetext{
${ }^{28}$ This standard data set is used by Marsh and Mrrton (1987), Fama and Frruch (1987), Camphrll and Shiller (1987), and Foterba and Summers (1987) among others.
} 
where $\mu_{t+1}^{\mathbf{P}}=\mathbf{r}_{1+1}-\mathbf{i}_{1}$. The joint hypotlyesis that equation (4.3) lonlels ancl expectations are rational implies that $\alpha=\lambda$ and $\beta=0 .^{29}$ The alternative liypothesis is that $\beta$ is lese or greater than zero: t.luat expected stock market returns are excessively or insufficiently volatile. respectively.

Table 5 presents estimates of equation (4.8). The first row reports the results from weekly data over the period 1973-84, using a seven-day elurodollar interest rale. The estimate of $\beta$ is -3.98 , and is atatistically different from zero at the one percent Ievel. Once again, the funding that $\beta<-1 / 2$ indicates that the lower variance bound is violated so that the forecast crror has greater variance than actual excess rcturus. The sccond row of Table 5 uses a seven-day interest rate on repurchase agrecments collateralized by U.S. government securities, which is available from DRI beginning in 1980. The coefficient here is statistically less than $-1 / 2$ at the une perent level. In rows 3 through 9 of Table 5 we report estimates of equation (4.9) for louger lonizoms (one month and one year) over the full Ibbotson sample and over 10 year subsamples. All but one of the estimates of $\beta$ are less than zero, though none is as large or statistically significant is in the weekly data. ${ }^{3031}$

\subsection{Excessive Forecast Volatility or Time-Varying Equity Premia?}

Naturally, an alternative explanation for the statistic ally significant confficients in Tables 4 and 5 is that the equity premium, $\lambda$, varies over time. Unfortuuately, we liave no survey data on stock returns to which we-can appeal. Nevertheless we can gain a cmde sense of whether a time-varying equity premium could be responsible for the results. If the foregoing negative coefficients were generated by a risk prenium, then when nominal iutcrest rates or price-dividend ratios are high, expected excess returns are low. Lower expected excess jeturns imply that the equity preminm, $\operatorname{cov},\left(\frac{-m_{t+1} \mathbf{q}_{t+1}}{\mathbf{q}_{t}}, 1+\mathbf{r}_{t+1}\right)$, must be high. In view of the large annunt of predictable variation in stock market variances and the consistently low variability of consumption, much of the variation in the equity prenium is likely to be due to changes in volatility of stock ret.ums. ${ }^{32}$ Indeed, Malkiel (1979) and Pindyck (1984) argue that market movements largely reffect movements in perceived

\footnotetext{
${ }^{29}$ If wr: include the sccond-order term, $\lambda I_{t}$, then the null hypothersis implies $n=A=\lambda$.

${ }^{20}$ Thr findings in Table 5 appear to be indeprndent of those in Tahle 4. When the rxerse market return is regresged simulaneously on the price-dividend ratio and the interest rate, both rorfirimats remain virtilally uurhanged from those reported in the tahles above. Indeed, the correlation lefwern the prier-lividrnd ratio and tile short-term interest rate in the 1926.85 sample is only 0.07 .

${ }^{11}$ A number of authors have found evidence of a megative correlatiou brtweru ahort.term nominal intrrest rateg and subsequent stock market. returns, both in the U.S. and in other iudustrialized roututrirs as wrll (arr Fama and Srhwrrt, 1977, and Solnik, 1983). This is usually interpreted to mean that st.ock returns reppourl negativerly to rxpertietl infation. Au intertemporal model of asset pricing, which posits correlation between contemporaneous irturns and future rxperterd returns is usually invoked to explain this correlation.

${ }^{33}$ Mrrton (1980) considers $x$ model in which expreted excess rrturns oll the market arr proportioulal to the variance.
} 
stock market volatility. ${ }^{33}$

This alternative hypothesis would then imply that the "xpected volatility of stock returns is negatively correlated with the price-dividend ratio and the interest rate. To test for this pattern, we regress a measure of volatility on price-dividend ratios and then on interest rates:

$$
\hat{\sigma}_{1.1+1} \mathbf{p}_{\boldsymbol{i}}=\alpha_{1}+\delta_{1} \mathbf{p}_{\boldsymbol{t}}+\eta_{1.1+1}
$$

and

$$
\tilde{\sigma}_{2,1+1}=\alpha_{2}+\delta_{2} i_{1}+\eta_{2.1+1}
$$

where $\hat{\sigma}_{1,1+1}$ is the unexpected return on the stock market from equation $(4.8)$, and $\hat{\sigma}_{2,1+1}$ is unexpected return on the stock market from equation (4.9). The time-varying equity premium hypothesis implies that $\delta_{i}<0$. Under rational expectations and the assumption that equation (4.10) is a complete nodel of the expected future variance. the error terms are attributable to news, and are therefore conditionally indepenclent of informationt available at time $t$. In case the error term contains left-out (orthogonal) variables we report standard errors using a covariance matrix estimator due to Newey and West (1985) which allows for unknown serial correlation.

Table $6 \mathrm{a}$ and $6 \mathrm{~b}$ present estimates of equations (4.10a) and (4.10) ), respectively. The estimates of $\delta_{1}$ in Table $6 a$ for different samples are of different signs. but muly the estimate in the first row is statistically significant at the 5 percent. level, and it is positive. Table 6l, reports estimates of the regression of unexpected returns on the interest rate. Here the estimates of $\delta_{2}$ for the seven-day holding periods are positive at the 5 percent level. Ou the other hand. the estimates for monthly and anmual holding periods are statistic ally less than z,ero. For the slooter holding periods, there is no evidence that the findings of excessively volatile expected returns can be interpreted as variation in the equity premia. ${ }^{34}$

\footnotetext{
${ }^{2 \pi}$ The analysis of Foterha and Summers (1987) argues against this alternative hypothesis. It. slows that while volatility rluanges are substartial, they do not appear to be prrsistemt enough to explain large movements in stock prices.

${ }^{34}$ Giovannini and Jotion (1987) regress the squared returns on a number of aserts on seven.day nnminal interest rates, and report results similar to those in Table oh. They alon find a signific antly positive relationship.
} 


\section{Conclusions}

We have developed several simple regression tests of excessive volatility iu the foreign exchange market. and the U.S. stock market. These tests are casy to iunplement and are free of many the small-sample difficultics that plague tests of variance bounds matious.

In the foreign exchange market, we find evidener (based nn new results and reintelpretations of old results) that exchange rates are excessively volatile. This finding holds whether expected future spot rates are measured using the forward rate or selrucy dat a mu cxchange rate expectations. One potential explanation for such excessive volatility is that "xpecterl ropreciation is too variable. We cite and confirm an abundauce of earlier evidence suggesting that expected exclange rate changes are indeed too volatile. Once again, this conclusinu holels regardless of whether the expected future spot rate is measured using the forward rate or survey rata.

We also find analogous evideuce of predictable variatimu in exerss stock niarket returns, which within our model can be iuterpreted as excessive stork price volatility and excessive volatility in expected stock market returns. For shorter holding pericuds. we fiurd un evidence that changes in perceived volatility could account for the movements in ecpity premia required to explain this excessive variation. Thus we join a host of other authors who reject the simple representative agent model of stock prices, but this time in favor of the specific alternative that expectations and stock prices are too variable. 


\section{References}

Bilson, J., "Rational Expectations and the Excliange Rate." in The Economics of Exchange Rates: Selected Readings, "ed. J.A. Frenkel and H. Inlmson. Addisnn-Wesley, 1978.

"The Speculative Efficiency Hypothesis, Journal of Business, Vol. 54, pp. 433-451.

Campbell, J.Y. and R.J. Shiller, "The Dividend-Prier Ratio and Expectations of Future Dividends and Discount. Factors," mimen, 1987.

Political Economy, 1987.

"Cointcgration and Tests of Present Value Models." fortheoming, Journal of

"A Simple Account of the Beliavior of Long-Term Interest Rates," American Economic Review, Vol. 74. No. 2, pp. 44-48. 1984.

Diba. B.T., "A Critique of Variance Bounds Tests for Mometary Excliange Rate Models," Journal of Money, Credit and Banking, Vol. 19. pp. 104-111.. 1987.

Dominguez, K., "Are Foreign Exchange Forerasts Rational: New Evidence from Survey Data," Economics Letters. Vol. pp. , 1986.

Dombusch, R., "Expectations and Exclange Rate Dyunmirs," Jnurnal of Political Economy, Vol. 84, pp. 1161-74, 1976.

Fama, E.F., "Forward and Spot Excliange Rates." Jnurnal of Monetary Economice, Vol. 36, pp. $697-703,1984$.

Fania, E.F., and K.R. French, "Permanent and Tempolary Components of Stock Prices," Center for Research in Sccurities Prices Working Paprer No. 178. University of Chicago, 1987.

Fama, E.F. and G.W. Schwert, "Assct Returns and Inflation." Journal of Financial Economics, Vol. 5, pp. 319-38, March 1977.

Flavin, M., "Excess Volatility in the Financial Markets: A Reassessment of the Empirical Evidence." Journal of Political Eronomy, Vol. 91.pp. 929-56, 1983.

Flood, R.P., R.J. Hodrick, and P. Kaplan. "An Evaluation of Recent Evidence on Stock Market Bubbles," NBER Working Paper No. 1971. 1986.

Frankel. J.A., "On the Mark: A Theory of Flnating Excliange Rates Based on Real Interest Differentials," American Economic Revirin. p1). GIn-622, 1970.

Frankel, J.A. and K.A. Froot, "Using Survey Data to Test Stanrlarel Propositions Regarding Exclaange Rate Expectations," American Eronnmic Rrvicm, Vol. 77, 1, pp. 133-153, 1987.

Frankel, J.A. and R. Mcese, "Are Exchange Rates Excessivcly Variable?," forthcoming in Macroeconomics Annunl, 1987, ed. S. Fischer. MIT Press. 1987.

Frankel, J.A. and J. Stock, "Regression vs. Volatility Tests of Forcign Exclange Markets," Journal of International Moncy and Finance. Vol 6. p1). 49-56, 1987.

Frenkel, J.A. "A Monetary Approach to the Excliange Rate: Dortrinal Aspects and Empirical Evidence, ${ }_{1}$ Scandinavian Journal of Economics. Vol. 78, pp. 200-24, 1976. 
Frenkel, J.A. and M.L. Mussa, “Asset. Markets, Excliange Rates, and the Balance of Payments," in R.W. Jones and P.B. Kenen eds., Handhok of Internntional Eronomics. Vol. 2, NorthHolland, 1985.

Froot, K.A., "New Hope for the Expectations Hypotliesis of the Term Structure of Interest Rates," Massachusetts Institute of Teclnolngy, 1987a.

, "Consistent Covariance Matrix Estination witlı Cross-Sectional Dependence and Heteroskedasticity in Cross-Sectional Financial Data." Massaclutsetts Institute of Technology, 1987b.

Froot, K.A. and J.A. Frankel, "Interpreting Tests of Forward Discomt Bias Using Survey Data on Excliange Rate Expectations," NBER Working Paper. no. 1963, 1986.

Giovannini, A. and P. Jorion, "Interest Rates and Risk Premia in the Stork Market and in the Foreign Excliange Market," Journal of International Money and Finance, Vol. 6, pp. 107-24, March 1987.

Hansen, L.P., "Large Sample Properties of Generalized Metlind of Monents Estimators," Econometrica, Vol. 50, pp. 1029-1054. 1982.

Hausen, L.P. and R..J. Hodrick, "Forward Rates as Optimal Predictors of Future Spot Rates: An Econometric Analysis," Journal of Political Eronomy. Vol. 88. pp. 829-53, 1980.

Hodrick, R.J., "The Empirical Evidence on the Efficiency of Forward and Futures Foreign Exchange Markets," fortheoming in Fundamentals of Pure and Applicd Eronomics, (Cur, Swit.7erland: Harwood Academic Publishers), 1987.

Hodrick, R.J., and S. Srivastava, "An Investigation of Risk and Retun in Forward Foreign Exchange," Journal of International Money and Finance. April 1984, 3, pp. 5-30.

Huang, R.D., "The Monetary Approach to Exchange Rates in an Efficient. Foreign Exchange Market: Tests based on Volatility." Journal of Finanre. Vol. 36. pp. 31-41, 1981.

"Some Alternative Tests of Forwarel Excliange Rates as Predictors of Fut.ure Spot Rates," Journal of Intcrnational Monry und Financr. Vnl. 3, jp. 153-67, 1984.

Ibbotson Associates, Stocks, Bonds, Bills and Inflation: 1986 Yearlonok, Ibbotson Associates, Chicago, 1986.

Keim D.B., and R.F. Stambaugh, "Predicting Returns in the Stock and Bond Markets," Journal of Financial Economics, Vol. 17, pp. 357-90. 1986.

Kleidon, A.W., "Variance Bounds Tests and Stork Price Vahıtion." Iournal of Political Economy, Vol. 94, pp. 953-1001, 1986.

LeRoy, S.F. and R.D. Porter, "The Present-Value Relation: Trats Based on Implied Variance Boluds," Econometrica, Vol. 49, pp. 555-574. 1081.

Malkiel, B.G., "The Capital Formation Problem in the U.S.." Inurnal of Finance, Vol. 34, pp. 369-81, May 1976.

Mankiw, N.G., D. Romer and M.D. Shapiro, "An Unbiased Recxanination of Stock Market Volatility," Journal of Finance, Vol. 40, pp 677-87. 1985.

Mankiw, N.G. and L.H. Summers, "Do Long-Term Interest. Rates Overreact to Short-Term 
Interest Rates?," Brookings Papers on Eronomic Artivity. No. 1. pp. 223-242, 1984.

Marsh, T. and R. Merton, "Dividend Variability and Variance Bounds Tests for the Rationality of Stock Market Prices," American Economic Revirim. Vol. 76. pp. 483-498, 1986.

"Dividend Belaavior for the Aggregatce Stock Market." Journal of Business, Vol. 60, pp. $1-40,1987$.

Mattey, J. and R.A. Mrese, "Empirical Assessment of Present Valuc Relations," fortheoning in Econometric Reviews, 1987.

Mecse, R.A. and K.J. Singletion, "Rational Expectations and the Volatility of Floating Exchange Rates," International Economic Reviren. Vol. 24. p1). 721-33. 1983.

Merton, R.C., "On Estimating the Expected Return on tlir Market.," Journal of Financial Economics, Vol. 8, pp. 323-61, December 1980.

Mussa, M.L., "The Excliange. Rate, the Balauce of Payments and Monetary and Fiscal Policy under a Regiune of Controlled Floating," Scandinasinn .Inurnal of Economics, Vol. 78, pp. 229-48, 1976.

Newey, W., and K. West., "A Siluple, Positive Definite. Hetcreskedasticity and Autocorrelation Consistent Covariance Matrix," Woodrow Wilson School Discussion Paper, No. 92, May 1985.

Pindyck, R.S., "Risk, Inflation, and the Stock Market." Americnn Econnmir Review, Vol. 74, pp. 335-51, June 1984.

Poterba, J.M. and L.H. Sumners, "The Persistenee of Volatility and Stock Market Fluctuations," American Economic Review, Vol. 76. pp. 1142-1151. 1986.

Scot.t, L.O., "The Present Value Model of Stock Prices: Rregression Tests and Monte Carlo Results." The Review of Economics and Statistics. pp. 599-605, 1985

Shiller, R.J., "Do Stock Prices Move Too Mucl to be Justified by Subsecquent Changes in Dividends?" American Economic Review. Vol. 71. pp. 421-436, 1981a.

"The Use of Volatility Measures in Assrssing Market Efficiency," Journal of Finance, Vol. 36, pp. 291-311. 1981 b.

Shiller, R.J., J.Y. Campbell and K.L. Schoenholt.7. "Forwarl Rates and Future Policy: Interpreting the Term Structure of Interest. Rates," Bronkingn Pupers on Economic Activity, No. 1, pp. 223-242, 1983.

Solnik, B., "The Rrlation Between Stock Prices aud Inflatiouary Expectations," Journal of Finance, Vol. 38, pp. 35-48, March 1983.

Vander Kraats, R.H. and L.D. Booth, "Empirical Tests of the Mourtary Approach to Exchange Rate Determination," Journal of International Money and Finance, Vol. 2, pp. 255-78, 1983.

West, K., "A Specification Test for Speculative Bubbles," Princeton Iniversity, 1984, revised 1986.

White, H., "A Heteroskedasticity-Consistent Covariance Matrix Estimator and a Direct Test for Heteroskedasticity, Econometrica, Vol. 48, pp. 817-38, May 1980. 

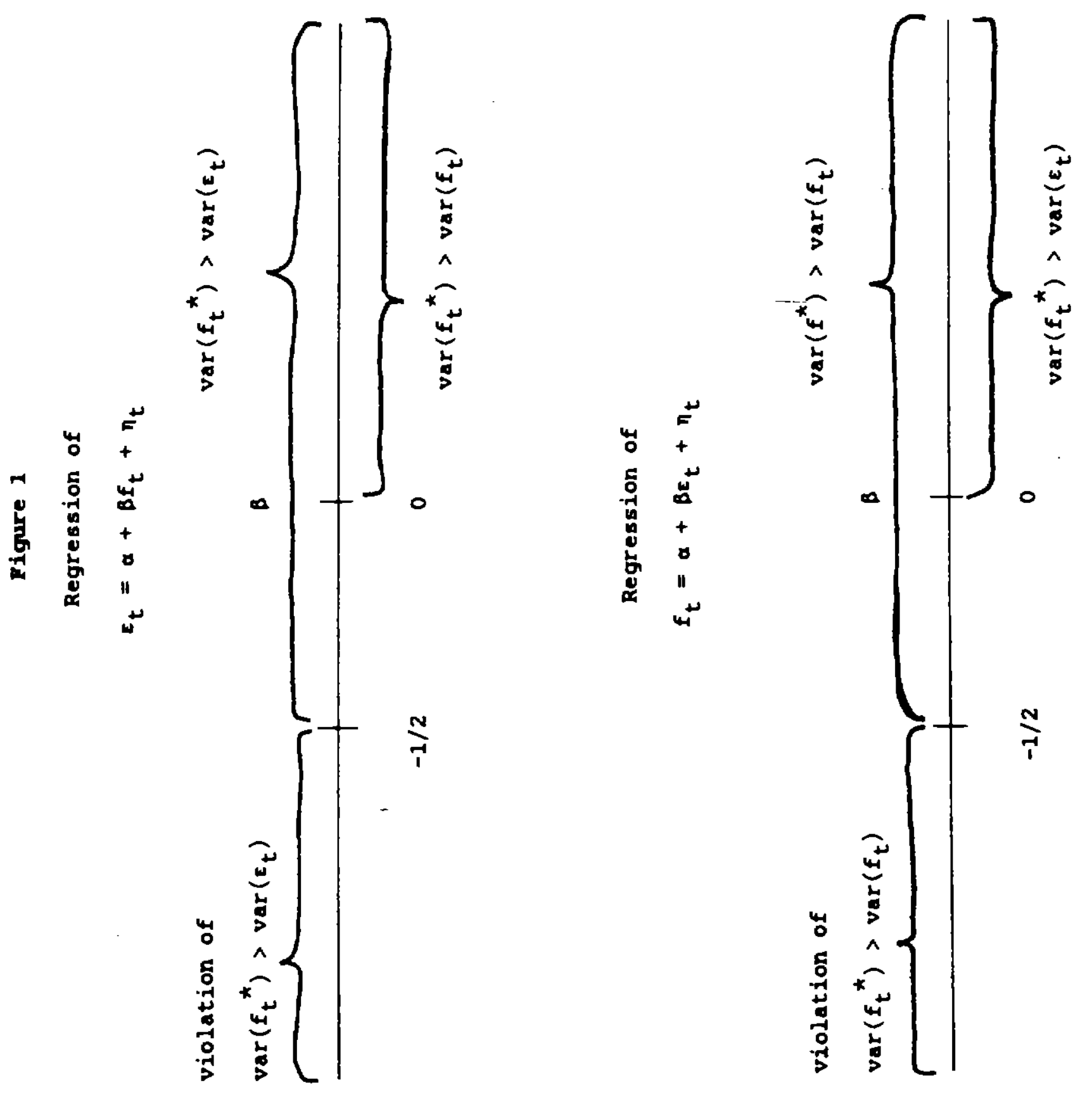
Table 1a

$$
\begin{aligned}
& \text { Regressions of } \\
& \mu_{t+1}^{t}=\alpha+B s_{t}+\varepsilon_{t+1}
\end{aligned}
$$

\begin{tabular}{|c|c|c|c|c|c|c|}
\hline Currency & B & $\tau: B=0$ & $\begin{array}{l}F \text { test } \\
\alpha=0 \\
B=0\end{array}$ & DN & $\mathrm{R}^{2}$ & DF \\
\hline $\mathrm{DM}$ & $\begin{array}{l}-.0224 \\
(.01829) \\
(.02042)\end{array}$ & $\begin{array}{l}-1.224 \\
-1.096\end{array}$ & $\begin{array}{l}1.497 \\
0.625\end{array}$ & 2.11 & .00 & 163 \\
\hline Pound & $\begin{array}{l}-.0179 \\
(.01214) \\
(.01489)\end{array}$ & $\begin{array}{l}-1.478 \\
-1.205\end{array}$ & $\begin{array}{l}2.184 \\
0.890\end{array}$ & 1.86 & .01 & 163 \\
\hline Yen & $\begin{array}{l}-.0048 \\
(.01548) \\
(.01512)\end{array}$ & $\begin{array}{l}-0.309 \\
-0.317\end{array}$ & $\begin{array}{l}0.096 \\
0.310\end{array}$ & 1.79 & .00 & 163 \\
\hline $\begin{array}{l}\text { Canadian } \\
\text { Dollar }\end{array}$ & $\begin{array}{l}-.0096 \\
(.00911) \\
(.00894)\end{array}$ & $\begin{array}{l}-1.051 \\
-1.071\end{array}$ & $\begin{array}{l}1.104 \\
0.890\end{array}$ & 2.07 & .00 & 163 \\
\hline Lira & $\begin{array}{l}-.0087 \\
(.00662) \\
(.00683)\end{array}$ & $\begin{array}{l}-1.316 \\
-1.276\end{array}$ & $\begin{array}{l}1.732 \\
0.981\end{array}$ & 1.96 & .00 & 163 \\
\hline $\begin{array}{l}\text { French } \\
\text { Franc }\end{array}$ & $\begin{array}{l}-.0136 \\
(.00988) \\
(.01074)\end{array}$ & $\begin{array}{l}-1.377 \\
-1.266\end{array}$ & $\begin{array}{l}1.895 \\
0.792\end{array}$ & 2.08 & .01 & 163 \\
\hline $\begin{array}{l}\text { All } \\
\text { Currencies } \\
\text { Above }\end{array}$ & $\begin{array}{l}-.0080 \\
(.0033)\end{array}$ & $-2.413^{\star t}$ & $2.395 \star \star$ & 1.97 & .00 & 983 \\
\hline
\end{tabular}

Notes: All estimates are monthly data from April 1973 to February 1987. The first six regressions are estimated using OLS, with standard errors (in parentheses) calculated using GM under homoskedasticity, and using White's heteroskedasticity correction, respectively. The last regression combines all six currencies, and is estimated using

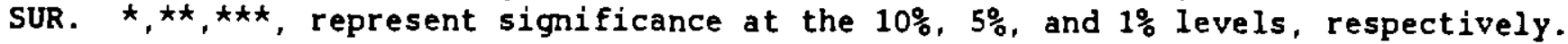


Table 1b

$$
\begin{gathered}
\text { Regressions of } \\
u_{t+1}^{f}=\alpha+\beta\left(s_{t}-s_{t-1}\right)+\varepsilon_{t+1}
\end{gathered}
$$

\begin{tabular}{|c|c|c|c|c|c|c|}
\hline Currency & B & $\tau: \beta=0$ & $\begin{array}{l}F \text { test } \\
C=0 \\
B=0\end{array}$ & Dw & $\mathrm{R}^{2}$ & DF \\
\hline DM & $\begin{array}{l}-.0182 \\
(.01839) \\
(.02029)\end{array}$ & $\begin{array}{l}-0.990 \\
-0.897\end{array}$ & $\begin{array}{l}0.985 \\
0.603\end{array}$ & 2.16 & .00 & 162 \\
\hline Pound & $\begin{array}{l}-.0175 \\
(.01217) \\
(.01451)\end{array}$ & $\begin{array}{l}-1.439 \\
-1.207\end{array}$ & $\begin{array}{l}2.069 \\
0.840\end{array}$ & 1.91 & .00 & 162 \\
\hline Yen & $\begin{array}{l}-.0085 \\
(.01585) \\
(.01502)\end{array}$ & $\begin{array}{l}-0.535 \\
-0.565\end{array}$ & $\begin{array}{l}0.286 \\
0.518\end{array}$ & 1.82 & .00 & 162 \\
\hline $\begin{array}{l}\text { Canadian } \\
\text { Dollar }\end{array}$ & $\begin{array}{l}-.0087 \\
(.00918) \\
(.00899)\end{array}$ & $\begin{array}{l}-0.949 \\
-0.969\end{array}$ & $\begin{array}{l}0.901 \\
0.744\end{array}$ & 2.10 & .00 & 162 \\
\hline Lira & $\begin{array}{l}-.0087 \\
(.00665) \\
(.00694)\end{array}$ & $\begin{array}{c}-1.311 \\
-1.257 \\
-\end{array}$ & $\begin{array}{l}1.720 \\
0.976\end{array}$ & 1.99 & .01 & 162 \\
\hline $\begin{array}{l}\text { French } \\
\text { Franc }\end{array}$ & $\begin{array}{l}-.0135 \\
(.00990) \\
(.01072)\end{array}$ & $\begin{array}{l}-1.364 \\
-1.259\end{array}$ & $\begin{array}{l}1.861 \\
0.784\end{array}$ & 2.11 & .01 & 162 \\
\hline $\begin{array}{l}\text { All } \\
\text { Currencies } \\
\text { Above }\end{array}$ & $\begin{array}{l}-.0075 \\
(.0033)\end{array}$ & $-2.25^{\star \star}$ & $2.477 \star \star$ & 1.99 & .00 & 977 \\
\hline
\end{tabular}

Notes: All estimates are monthly data from April 1973 to February 1987. The first six regressions are estimated using OLS, with standard errors (in parentheses) calculated using GMM under homoskedasticity, and using White's heteroskedasticity correction, respectively. The last regression combines all six currencies, and is estimated using

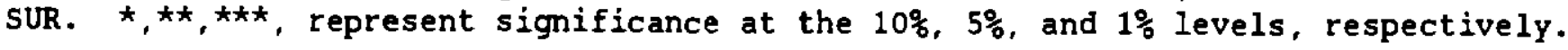


Table 1c

$$
\begin{aligned}
& \text { Regressions of } \\
& u_{t+1}^{f}=a+B\left(s_{t}-\bar{s}_{t}\right)+\varepsilon_{t+1}
\end{aligned}
$$

\begin{tabular}{|c|c|c|c|c|c|c|}
\hline Currency & B & $\tau: \beta=0$ & $\begin{array}{l}F \text { test } \\
\alpha=0 \\
\beta=0\end{array}$ & DN & $\mathrm{R}^{2}$ & DF \\
\hline DM & $\begin{array}{l}-.0152 \\
(.01384) \\
(.01406)\end{array}$ & $\begin{array}{l}-1.096 \\
-1.079\end{array}$ & $\begin{array}{l}1.202 \\
0.588\end{array}$ & 2.12 & .00 & 163 \\
\hline Pound & $\begin{array}{l}-.0084 \\
(.00765) \\
(.00812)\end{array}$ & $\begin{array}{l}-1.093 \\
-1.030\end{array}$ & $\begin{array}{l}1.195 \\
0.703\end{array}$ & 1.86 & .00 & 163 \\
\hline Yen & $\begin{array}{l}-.0047 \\
(.01151) \\
(.00966)\end{array}$ & $\begin{array}{l}-0.410 \\
-0.488\end{array}$ & $\begin{array}{l}0.168 \\
0.430\end{array}$ & 1.79 & .00 & 163 \\
\hline $\begin{array}{l}\text { Canadian } \\
\text { Dollar }\end{array}$ & $\begin{array}{l}-.0037 \\
(.00707) \\
(.00648)\end{array}$ & $\begin{array}{l}-0.519 \\
-0.566\end{array}$ & $\begin{array}{l}0.269 \\
0.635\end{array}$ & 2.11 & .00 & 162 \\
\hline Lira & $\begin{array}{l}-.0047 \\
(.00387) \\
(.00409)\end{array}$ & $\begin{array}{l}-1.204 \\
-1.140\end{array}$ & $\begin{array}{l}1.450 \\
0.771\end{array}$ & 1.99 & .00 & 162 \\
\hline $\begin{array}{l}\text { French } \\
\text { Franc }\end{array}$ & $\begin{array}{l}-.0094 \\
(.00739) \\
(.00802)\end{array}$ & $\begin{array}{c}- \\
-1.258 \\
-1.160\end{array}$ & $\begin{array}{l}1.583 \\
0.669\end{array}$ & 2.11 & .00 & 162 \\
\hline $\begin{array}{l}\text { All } \\
\text { Currencies } \\
\text { Above }\end{array}$ & $\begin{array}{l}-0,035 \\
(0 \$ 019)\end{array}$ & $-1.844^{\star}$ & $2.258 \star \star$ & 1.98 & .00 & 980 \\
\hline
\end{tabular}

Notes: All estimates are monthly data from April 1973 to February 1987. The first six regressions are estimated using oLs, with standard errors (in parentheses) calculated using GMM under homoskedasticity, and using White's heteroskedasticity correction, respectively. The last regression combines all six currencies, and is estimated using SUR. $\star, \star \star, \star \star \star$, represent significance at the $10 \%, 5 \%$, and $1 \%$ levels, respectively. 
Table 2a

Regressions of

$\mu_{t+1}^{e}=\alpha+B s_{t}+e_{t+1}$

\begin{tabular}{|c|c|c|c|c|c|c|c|}
\hline Data set & Dates & B & $\tau: \beta=0$ & $\begin{array}{l}F \text { test } \\
a=0 \\
\beta=0\end{array}$ & DN & $\mathrm{R}^{2}$ & DF \\
\hline MMS 1 week & $10 / 84-2 / 86$ & $\begin{array}{l}-.02983 \\
(.02931)\end{array}$ & -1.018 & 1.02 & 1.87 & .02 & 242 \\
\hline MMS 2 week & $1 / 83-10 / 84$ & $\begin{array}{l}-.08062 \\
(.03270)\end{array}$ & $-2.465 \star \star$ & $3.65 \star \star \star$ & 1.89 & .16 & 182 \\
\hline MMS 1 month & $10 / 84-2 / 86$ & $\begin{array}{l}-.02277 \\
(.08505)\end{array}$ & -0.268 & 1.20 & NA & .14 & 171 \\
\hline
\end{tabular}

Table 2b

Regressions of

$\mu_{t+1}^{e}=\alpha+B\left(s_{t}-s_{t-1}\right)+\varepsilon_{t+1}$

\begin{tabular}{|c|c|c|c|c|c|c|c|}
\hline Data set & Dates & B & $\tau: B=0$ & $\begin{array}{l}F \text { test } \\
B=0 \\
B=0\end{array}$ & DN & $\mathbf{R}^{2}$ & DF \\
\hline MMS 1 week & $10 / 84-2 / 86$ & $\begin{array}{l}-.19004 \\
(.12596)\end{array}$ & -1.509 & 1.26 & 1.69 & .03 & 242 \\
\hline MMS 2 week & $1 / 83-10 / 84$ & $\begin{array}{l}-.06511 \\
(.11867)\end{array}$ & -0.549 & $2.30 \star \star \star$ & 1.85 & .10 & 182 \\
\hline MMS 1 month & $10 / 84-2 / 86$ & $\begin{array}{l}-.14297 \\
(.16909)\end{array}$ & -0.845 & 1.32 & NA & .15 & 171 \\
\hline
\end{tabular}

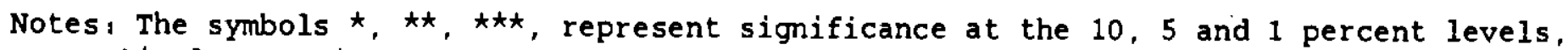
respectively. Estimates are aggregated over 4 currencies, the pound, deutsch mark, swiss franc, and yen. Standard errors (reported in parentheses) are GMM without heteroskedasticity correction. Overlapping observations in the one month data are acounted for by allowing the residuals to follow an MA(3) process. 
Table 2c

$$
\begin{aligned}
& \text { Regressions of } \\
& \mu_{t+1}^{e}=a+B\left(s_{t}-\sigma_{t}\right)+\varepsilon_{t+1}
\end{aligned}
$$

\begin{tabular}{|c|c|c|c|c|c|c|c|}
\hline Data set & Dates & B & $I: \beta=0$ & $\begin{array}{l}F \text { test } \\
\alpha=0 \\
\beta=0\end{array}$ & DH & $\mathrm{R}^{2}$ & DF \\
\hline MMS 1 week & $10 / 84-2 / 86$ & $\begin{array}{l}-.0544 \\
(.0349)\end{array}$ & -1.559 & 1.655 & 1.88 & .036 & 222 \\
\hline
\end{tabular}

MMS 2 week

$$
1 / 83-10 / 84
$$

$-2.381 \star \star$

$3.57 \star \star \star \star$

1.90

MAS 1 month

$$
10 / 84-2 / 86
$$

$\begin{array}{ll}-.11421 & -1.155 \\ (.09891) & \end{array}$

1.23

NA

Notes: The symbols $\star, \star \star, \star \star \star$, represent significance at the 10,5 and 1 percent levels, respectively. Estimates are aggregated over 4 currencies, the pound, deutsch mark, swiss franc, and yen. Standard errors (reported in parentheses) are GM without heteroskedasticity correction. Overlapping observations in the one month data are accounted for by allowing the residuals to follow an MA(3) process. 
Table 3

$$
\begin{aligned}
& \text { Regressions of } \\
& \mu_{t+1}^{f}=a+B\left(s_{t}-f_{t}\right)+\varepsilon_{t+1}
\end{aligned}
$$

\begin{tabular}{|c|c|c|c|c|c|c|}
\hline Currency & B & $\tau: B=0$ & $\begin{array}{l}F \text { test } \\
\alpha=0 \\
B=0\end{array}$ & $\mathbf{D W}$ & $\mathrm{R}^{2}$ & DF \\
\hline DM & $\begin{array}{l}-3.0069 \\
(1.05820) \\
(1.06129)\end{array}$ & $\begin{array}{l}-2.842^{\star \star \star} \\
-2.723^{\star \star \star}\end{array}$ & $\begin{array}{l}8.074^{\star \star \star \star} \\
3.700^{\star \star}\end{array}$ & 2.19 & .04 & 163 \\
\hline Pound & $\begin{array}{l}-3.0902 \\
(0.76997) \\
(0.71580)\end{array}$ & $\begin{array}{l}-4.013 \star \star \star \\
-4.317 \star \star \star\end{array}$ & $\begin{array}{r}16.107 \star \star \star \\
9.241 \star \star \star\end{array}$ & 2.04 & .08 & 163 \\
\hline Yen & $\begin{array}{l}-0.6741 \\
(0.46414) \\
(0.52760)\end{array}$ & $\begin{array}{l}-1.452^{\star} \\
-1.278\end{array}$ & $\begin{array}{l}2.109 \\
1.157\end{array}$ & 1.86 & .01 & 163 \\
\hline $\begin{array}{l}\text { Canadian } \\
\text { Dollar }\end{array}$ & $\begin{array}{l}-2.0268 \\
(0.65302) \\
(0.63655)\end{array}$ & $\begin{array}{l}-3.104 \star \star \star \\
-3.184 \star \star \star\end{array}$ & $\begin{array}{l}9.633 \star \star \star \\
6.136 \star \star \star\end{array}$ & 2.19 & .05 & 163 \\
\hline Lira & $\begin{array}{l}-1.3784 \\
(0.47159) \\
(0.50022)\end{array}$ & $\begin{array}{l}-2.923 \star \star \star \\
-2.756 \star \star \star\end{array}$ & $\begin{array}{l}8.543^{\star \star \star} \\
4.087 \star \star\end{array}$ & 2.03 & .04 & 163 \\
\hline $\begin{array}{l}\text { French } \\
\text { Franc }\end{array}$ & $\begin{array}{l}-1.7532 \\
(0.62255) \\
(0.76800)\end{array}$ & $\begin{array}{l}-2.816 \star \star \star \\
-2.283^{\star} \star\end{array}$ & $\begin{array}{l}7.931 \star \star \star \\
2.578 \star\end{array}$ & 2.18 & .04 & 163 \\
\hline $\begin{array}{l}\text { All } \\
\text { Currencies } \\
\text { Above }\end{array}$ & $\begin{array}{l}-1.5201 \\
(0.35854) \\
(0.44087)\end{array}$ & $\begin{array}{l}-4.240 \star \star \star \\
-3.448 \star \star \star\end{array}$ & $\begin{array}{l}3.042^{\star \star \star} \\
1.897 \star\end{array}$ & 2.07 & .03 & 983 \\
\hline
\end{tabular}

Notes: All estimates are monthly data from April 1973 to February 1987. The first six regressions are estimated using oLs, with standard errors (in parentheses) calculated using GMM under homoskedasticity, and using White's heteroskedasticity correction, respectively. The last regression combines all six currencies, and is estimated with OLS. $\star, \star \star, \star \star \star$, represent significance at the $10 \%, 5 \%$, and $1 \%$ levels, respectively. 
Table 4

OLS Regressions

$$
\mu_{t+1}^{P}=\alpha+B\left(P_{t} / x_{t}\right)+\varepsilon_{t+1}
$$

\begin{tabular}{|c|c|c|c|c|c|c|c|}
\hline $\begin{array}{c}\text { "Naive" } \\
\text { Forecast } \\
\mathbf{x}_{\mathbf{t}}\end{array}$ & dates & B & $t: B=0$ & $\begin{array}{c}F \text { Test } \\
\alpha=0 \\
\beta=0\end{array}$ & DN & $\mathbf{R}^{2}$ & DF \\
\hline$d_{t}$ & $\begin{array}{l}1926-85 \\
\text { monthly }\end{array}$ & $\begin{array}{c}.0031 \\
(0.0033) \\
(0.0045)\end{array}$ & $\begin{array}{l}0.928 \\
0.682\end{array}$ & $\begin{array}{l}0.03 \\
0.02\end{array}$ & 1.89 & .00 & 717 \\
\hline$d_{t}$ & $\begin{array}{l}1926-85 \\
\text { yearly }\end{array}$ & $\begin{array}{l}-0.0098 \\
(0.0042) \\
(0.0041)\end{array}$ & $\begin{array}{l}-2.335 \star \star \\
-2.410 \star \star\end{array}$ & $\begin{array}{l}6.73 \star \star \star \\
4.92 \star \star \star\end{array}$ & 1.83 & .07 & 56 \\
\hline$d_{t}$ & $\begin{array}{l}1936-85 \\
\text { monthly }\end{array}$ & $\begin{array}{c}0.0005 \\
(0.0031) \\
(0.0042)\end{array}$ & $\begin{array}{l}0.147 \\
0.108\end{array}$ & $\begin{array}{l}2.78 \star \star \\
4.61 \star \star \star\end{array}$ & 1.95 & .00 & 597 \\
\hline$d_{0}$ & $\begin{array}{l}1936-85 \\
\text { monthly }\end{array}$ & $\begin{array}{l}-0.0154 \\
(0.0070) \\
(0.0071)\end{array}$ & $\begin{array}{l}-2.192^{\star \star} \\
-2.156^{\star \star}\end{array}$ & $\begin{array}{l}6.80 \star \star \star \\
7.51 \star \star \star\end{array}$ & 1.88 & .01 & 597 \\
\hline$d_{0}$ & $\begin{array}{l}1976-85 \\
\text { monthly }\end{array}$ & $\begin{array}{l}-0.1070 \\
(0.0459) \\
(0.0464)\end{array}$ & $\begin{array}{l}-2.332 \star \star \\
-2.306 \star \star\end{array}$ & $\begin{array}{l}3.30 \star \star \\
2.99^{\star}\end{array}$ & 1.87 & .04 & 117 \\
\hline$d_{0}$ & $\begin{array}{l}1966-75 \\
\text { monthly }\end{array}$ & $\begin{array}{l}-0.0341 \\
(0.0242) \\
(0.0263)\end{array}$ & $\begin{array}{l}-1.407 \\
-1.293\end{array}$ & $\begin{array}{l}1.03 \\
0.95\end{array}$ & 1.76 & .01 & 117 \\
\hline$d_{0}$ & $\begin{array}{l}1956-65 \\
\text { monthly }\end{array}$ & $\begin{array}{l}-0.0256 \\
(0.0252) \\
(0.0219)\end{array}$ & $\begin{array}{l}-1.016 \\
-1.170\end{array}$ & $\begin{array}{l}3.40 \star \star \\
3.21 \star \star\end{array}$ & 1.67 & .01 & 117 \\
\hline$d_{0}$ & $\begin{array}{l}1946-55 \\
\text { monthly }\end{array}$ & $\begin{array}{l}-0.0275 \\
(0.0264) \\
(0.0271)\end{array}$ & $\begin{array}{l}-1.040 \\
-1.014\end{array}$ & $\begin{array}{l}4.85 \star \star \star \\
6.49 \star \star \star\end{array}$ & 1.80 & .00 & 117 \\
\hline$d_{0}$ & $\begin{array}{l}1936-45 \\
\text { monthly }\end{array}$ & $\begin{array}{l}-0.0255 \\
(0.0345) \\
(0.0369)\end{array}$ & $\begin{array}{l}-0.740 \\
-0.692\end{array}$ & $\begin{array}{l}1.33 \\
1.31\end{array}$ & 2.05 & .00 & 117 \\
\hline
\end{tabular}

Notes: Standard errors (in parentheses) are computed using GMM under the assumption of homoskedasticity and also allowing for conditional

heteroskedasticity, respectively. $\star, \star \star, \star \star \star$ represent significance at the 10,5 and 1 percent levels, respectively. $d_{t}$ respresents current dividends, $d_{0}$ is an average of the past 120 months of dividends. 
Table 5

Regressions of

$$
\mu_{t+1}^{p}=\alpha+\beta i_{t}+\varepsilon_{t+1}
$$

\begin{tabular}{|c|c|c|c|c|c|c|}
\hline dates & $\boldsymbol{\beta}$ & $t: \beta=0$ & $\begin{array}{c}\text { F Test } \\
\alpha=0 \\
\beta=0\end{array}$ & DA & $\mathrm{R}^{2}$ & DF \\
\hline $\begin{array}{l}1973-84 \\
\text { weekly }\end{array}$ & $\begin{array}{l}-3.9752 \\
(1.2865) \\
(1.1980)\end{array}$ & $\begin{array}{l}-3.090 \star \star \star \\
-3.318 \star \star \star\end{array}$ & $\begin{array}{l}6.91 \star \star \star \\
6.47 \star \star \star\end{array}$ & 1.99 & .01 & 602 \\
\hline $\begin{array}{l}1980-86 \\
\text { weekly }\end{array}$ & $\begin{array}{l}-6.2372 \\
(1.9628) \\
(2.0268)\end{array}$ & $\begin{array}{l}-3.178 \star \star \star \\
-3.077 \star \star \star\end{array}$ & $\begin{array}{l}5.50 \star \star \star \\
6.06 \star \star \star\end{array}$ & 1.98 & .03 & 310 \\
\hline $\begin{array}{l}1926-85 \\
\text { monthly }\end{array}$ & $\begin{array}{l}-1.3623 \\
(0.7746) \\
(0.7806)\end{array}$ & $\begin{array}{l}-1.759^{\star} \\
-1.745^{\star}\end{array}$ & $\begin{array}{l}6.14^{\star \star \star} \\
5.00 \star \star \star\end{array}$ & 1.78 & .00 & 717 \\
\hline $\begin{array}{l}1926-85 \\
\text { yearly }\end{array}$ & $\begin{array}{l}-1.4216 \\
(0.8405) \\
(0.7502)\end{array}$ & $\begin{array}{l}-1.691 \star \\
-1.895^{\star}\end{array}$ & $\begin{array}{l}5.36 \star \star \star \\
4.16 \star \star\end{array}$ & 1.99 & .03 & 57 \\
\hline $\begin{array}{l}1976-85 \\
\text { monthly }\end{array}$ & $\begin{array}{l}-1.5010 \\
(1.5249) \\
(1.5787)\end{array}$ & $\begin{array}{l}-0.984 \\
-0.951\end{array}$ & $\begin{array}{l}1.23 \\
1.53\end{array}$ & 2.01 & .00 & 117 \\
\hline $\begin{array}{l}1966-75 \\
\text { monthly }\end{array}$ & $\begin{array}{l}-2.6972 \\
(3.7199) \\
(5.2715)\end{array}$ & $\begin{array}{l}-0.725 \\
-0.512\end{array}$ & $\begin{array}{l}0.26 \\
0.18\end{array}$ & 1.84 & .00 & 117 \\
\hline $\begin{array}{l}1956-65 \\
\text { monthly }\end{array}$ & $\begin{array}{l}-9.4751 \\
(4.5716) \\
(3.6000)\end{array}$ & $\begin{array}{l}-2.073^{\star} \star \\
-2.632 \star \star \bar{\star}\end{array}$ & $\begin{array}{l}5.30 \star \star \star \\
6.41 \star \star \star\end{array}$ & 1.75 & .03 & 117 \\
\hline $\begin{array}{l}1946-55 \\
\text { monthly }\end{array}$ & $\begin{array}{c}5.4463 \\
(7.6623) \\
(8.2318)\end{array}$ & $\begin{array}{l}0.456 \\
0.419\end{array}$ & $\begin{array}{l}4.42 \star \star \\
5.25 \star \star \star\end{array}$ & 1.89 & .00 & $1: 7$ \\
\hline $\begin{array}{l}1936-45 \\
\text { monthly }\end{array}$ & $\begin{array}{c}-4.5518 \\
(36.6668) \\
(33.9483)\end{array}$ & $\begin{array}{l}-0.124 \\
-0.134\end{array}$ & $\begin{array}{l}1.27 \\
1.40\end{array}$ & 2.22 & .00 & 117 \\
\hline $\begin{array}{l}1926-35 \\
\text { monthly }\end{array}$ & $\begin{array}{l}-4.7814 \\
(6.0698) \\
(5.4677)\end{array}$ & $\begin{array}{l}-0.788 \\
-0.874\end{array}$ & $\begin{array}{l}0.60 \\
0.47\end{array}$ & 1.52 & .00 & 117 \\
\hline
\end{tabular}

Notes: Standard errors (in parentheses) are computed using GMM under the assumption of homoskedasticity and also allowing for conditional

heteroskedasticity, respectively. $\star, \star \star, \star \star \star \star$ represent significance at the 10,5 and 1 percent levels, respectively. 
Table 6a

$$
\begin{gathered}
\text { OLS Regressions of } \\
\sigma_{1, t+1}^{2}\left(P_{t} / x_{t}\right)=a_{1}+\delta_{1}\left(P_{t} / x_{t}\right)+\varepsilon_{t+1}
\end{gathered}
$$

\begin{tabular}{|c|c|c|c|c|c|}
\hline $\begin{array}{c}\text { "Naive" Forecast } \\
x_{t}\end{array}$ & $\begin{array}{l}\text { Data Set } \\
\text { Dates }\end{array}$ & $\delta_{1}$ & $t: \delta_{1}=0$ & $\overline{\mathrm{R}}^{2}$ & DN \\
\hline$d_{t}$ & $\begin{array}{l}1926-85 \\
\text { monthly }\end{array}$ & $\begin{array}{c}0.0011 \\
(0.0004) \\
(0.0003)\end{array}$ & $\begin{array}{l}2.632 \star \star \star \\
3.442 \star \star \star\end{array}$ & .01 & 1.59 \\
\hline$d_{t}$ & $\begin{array}{l}1926-85 \\
\text { annua } 1\end{array}$ & $\begin{array}{l}-0.0002 \\
(0.0001) \\
(0.0001)\end{array}$ & $\begin{array}{l}-2.209 \star \star \\
-1.862 \star\end{array}$ & .07 & 1.42 \\
\hline$d_{0}$ & $\begin{array}{l}1936-85 \\
\text { monthly }\end{array}$ & $\begin{array}{l}-0.0011 \\
(0.0006) \\
(0.0007)\end{array}$ & $\begin{array}{l}-1.913^{\star} \\
-1.538\end{array}$ & .01 & 1.90 \\
\hline
\end{tabular}

Table 6b

OLS Regressions of

$\sigma_{2, t+1}^{2}=a_{2}+\delta_{2} i_{t}+\varepsilon_{t+1}$

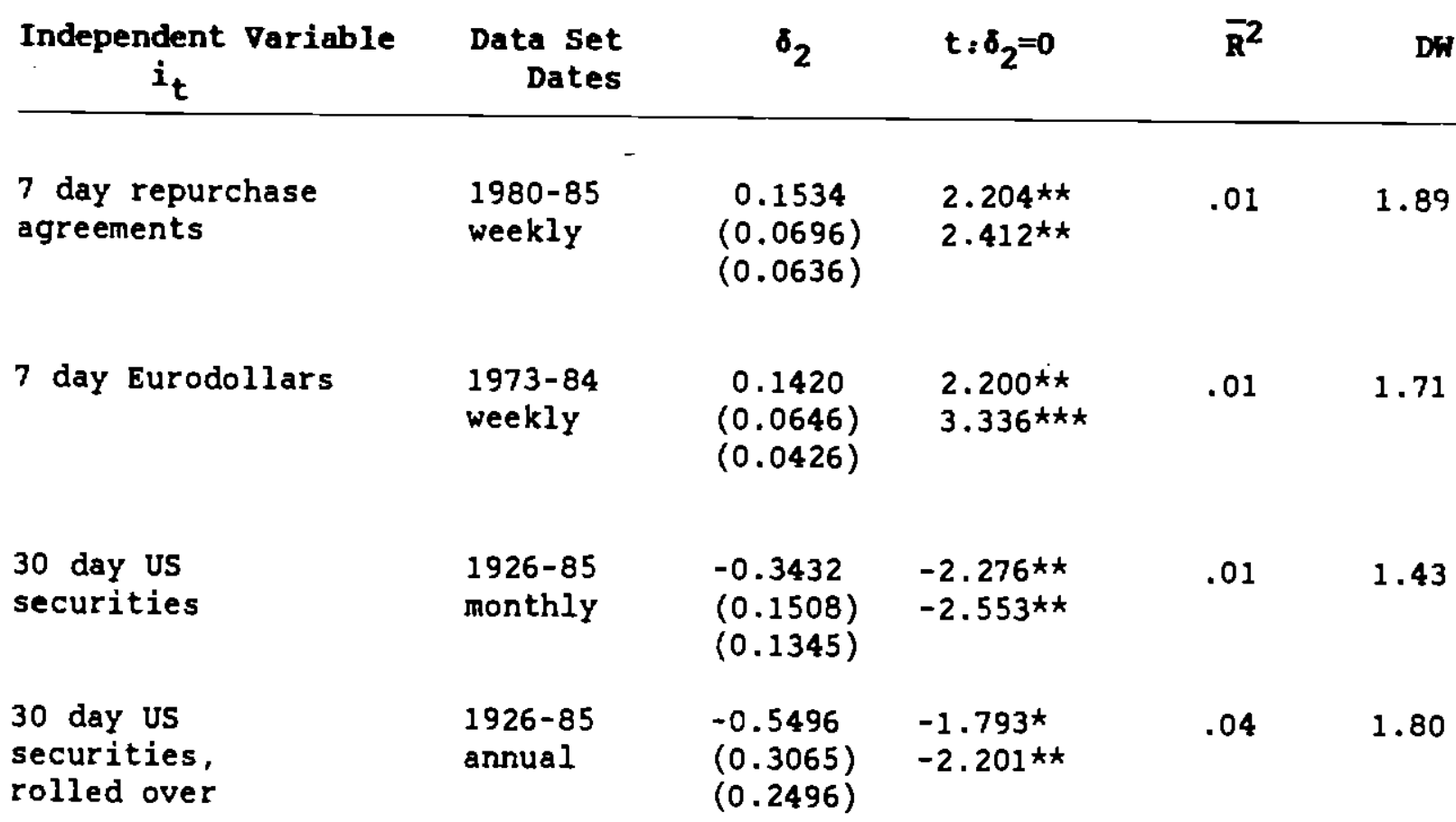

Notes: The symbols, $\star, \star \star, \star \star \star$ represent significance at the 10,5 and 1 percent levels, respectively. Standard errors (in parentheses) are computed using GM with and without a heteroskedasticity correction. 